\author{
Johann Humberto Penuela Munoz
}

\title{
Analysis of Drop Breakup Phenomenon of Diluted Oil in Water Emulsions in Turbulent Flow
}

\section{DISSERTAÇÃO DE MESTRADO}

Dissertation presented to the Programa de Pós Graduação em Engenharia Mecânica of the Departamento de Engenharia Mecânica, PUC Rio as a partial fulfillment of the requirements for the degree of Mestre em Engenharia Mecânica.

Advisor. Prof. Márcio da Silveira Carvalho

Rio de Janeiro

May 2014 
Johann Humberto Penuela Munoz

\section{Analysis of Drop Breakup Phenomenon of Diluted Oil in Water Emulsions in Turbulent Flow}

Dissertation presented to the Programa de Pós Graduação em Engenharia Mecânica of the Departamento de Engenharia Mecânica, PUC Rio as a partial fulfillment of the requirements for the degree of Mestre em Engenharia Mecânica.

Prof. Márcio da Silveira Carvalho Advisor

Departamento de Engenharia Mecânica - PUC-Rio

Prof. Luiz Fernando Alzuguir Azevedo Departamento de Engenharia Mecânica - PUC-Rio

Prof. Geraldo Afonso Spinelli Martins Ribeiro Departamento de Engenharia Mecânica - PUC-Rio

Prof. Paulo Roberto de Souza Mendes Departamento de Engenharia Mecânica - PUC-Rio

Prof. José Eugenio Leal Coordinator of the Centro Técnico Científico - PUC-Rio

Rio de Janeiro, May 5th, 2014. 
All rights reserved.

\section{Johann Humberto Penuela Munoz}

Holds a Bachelor's degree in Chemical Engineering by Universidad Industrial de Santander, Colombia in 2008. Has been involved in research projects related to the development of technologies for hydrocarbon transport in pipelines supported by the Colombian Institute of Petroleum. Member of the Society of Petroleum Engineers.

Bibliographic data

Penuela Munoz, Johann Humberto.

Analysis of drop breakup phenomenon of diluted oil-in-water emulsions in turbulent flow / Johann Humberto Penuela Munoz; Advisor: Márcio da Silveira Carvalho.

115 p.: il.; $30 \mathrm{~cm}$

Dissertação (Mestrado)-Pontifícia Universidade Católica do Rio de Janeiro, Departamento de Engenharia Mecânica, 2014.

Inclui bibliografia

1. Engenharia mecânica - Teses. 2. Quebra de gota. 3. Emulsões. 4. Visualização 5. Escoamento turbulento. I. Carvalho, Márcio da Silveira. II. Pontifícia Universidade Católica do Rio de Janeiro. Departamento de Engenharia Mecânica. III. Título. 
To Kelly,

Your love gives meaning to my life. 


\section{Acknowledgements}

To God, for all blessings he has gave me in all my life.

I owe my amorous thanks to my girlfriend Kelly. Without her love, encouragement and understanding, it would have been impossible for me to finish this work. My deepest gratitude goes especially to my mom, my brother and my entire family for their inexorable love and support throughout my life. I also would like to thank to Kelly's family for loving me like one more of them, and to Mrs. Maria Jose for treating us, Kelly and me, as their own children during our stay in Brazil. To all of them I dedicate this thesis.

I would like to express my gratitude to all those who gave me the possibility to complete this dissertation. I am deeply indebted to my advisor Prof. Márcio Carvalho whose help, inspiring suggestions and encouragement helped me in all the time of my research. My thanks and appreciation goes also to all staff of the Mechanical Engineering Department of PUC Rio, for giving me the opportunity to develop this work and contribute to my personal and professional improvement; to all members of evaluation committee for their observations and contributions to this work, to Brazilian research funding agencies CAPES and FAPERJ and finally to CHEVRON because their sponsorship in this investigation.

I could not forget to thank to my colleagues and soccer friends of PUC Rio, for their friendship and for make my permanence in Brazil a funny experience. 


\section{Abstract}

Penuela Munoz, Johann Humberto; Carvalho, Márcio da Silveira (Advisor). Analysis of drop breakup phenomenon of diluted oil in water emulsions in turbulent flow. Rio de Janeiro, 2014. 115p. MSc. Dissertation Department of Mechanical Engineering, Pontifícia Universidade Católica do Rio de Janeiro.

A high-speed camera has been used to visualize the drop breakup process at turbulent conditions in a rotor - stator mixer and through an orifice in a pipe. Two special cases were considered: the breakup of diluted emulsions and the breakup of single oil droplets. Two mineral oils of moderate viscosity were dispersed in two different continuous phases, tap water and a continuous phase formed by a mixture of substitute ocean water and the anionic surfactant STEOL® CS-330 (Stepan Company). For the case of breakup in the rotor - stator mixer, two mechanisms were identified. An initial fragmentation is caused by the combination of the vortex (generated by the circular motion of the rotor) and the jet zone emerging from the stator holes. The second mechanism is a mechanical breakup caused by the high shear stresses that droplets suffer in the rotor - stator gap. In the case of breakup through an orifice in a pipe, it was shown that breakage only occurs downstream of the restriction and takes place at a certain distance from the edge of the orifice. At this breakup length, the radial velocity gradient in the flow is large enough to overcome the resistance stresses (exerted by the droplet) and produce the rupture of the droplet. These results were in agreement with previous observations made Galinat et al. (2005) for the case of drop breakup through an orifice plate. However, from the observations made in this work, it was possible to conclude that the orifice length does not influence the breakup mechanisms. In addition, visualization has allowed to analyze the relative influence of interfacial tension and dispersed phase viscosity for both cases. Experimental values for the maximum stable drop diameter were obtained for the breakup of diluted oil-in-water emulsions in both studied cases. Analysis of the data revealed that maximum stable drop sizes were in the inertial sub range, characterized exclusively by the energy dissipation rate per unit mass, $\varepsilon$. A linear mechanistic model for the inertial sub-range, based in Kolmogorov's theory of 
isotropic turbulence, was developed to aid in data interpretation and to provide a basis for correlation. The model was adjusted to experimental data using a nonlinear optimization tool based in the generalized reduced gradient code (GRG2), and its precision was calculated from the root mean squared difference between experimental and predicted data. Good predictions were obtained for the breakup in the mixer; however, this was not the case for the breakup through the orifice. The relative low precision of the model used to correlate the breakup through the restriction lied in the lack of consideration of the time scale required for the breakup. In addition, a linear curve fitting based in a power law model, showed that interfacial effects drive the breakup process in the restriction.

\section{Keywords}

Drop breakup; emulsions; visualization; turbulent flow. 


\section{Resumo}

Penuela Munoz, Johann Humberto; Carvalho, Márcio da Silveira. Análise do fenômeno de quebra de gota de emulsões de óleo em agua diluídas em escoamento turbulento. Rio de Janeiro, 2014. 115p. Dissertação de Mestrado - Departamento de Engenharia Mecânica, Pontifícia Universidade Católica do Rio de Janeiro.

Uma câmera de alta velocidade foi utilizada para visualizar o processo de quebra de gota em um misturador rotor - estator e através de um orifício em um duto em condições de escoamento turbulento. Dois casos especiais foram considerados: quebra de emulsões diluídas e quebra de gotículas de óleo individuais. Dois óleos minerais de viscosidade moderada foram dispersos em duas fases continuas diferentes, água da torneira e uma fase contínua formada por uma mistura de água do mar padrão e o surfactante aniônico STEOL® CS-330 (Stepan Company). No caso de quebra no misturador rotor - estator, dois mecanismos foram identificados. Uma fragmentação inicial é causada pela combinação do vórtice (gerado pelo movimento circular do rotor) e a região de jato emergente dos furos do estator. O segundo mecanismo é uma quebra mecânica causada pelas altas taxas de cisalhamento que as gotas sofrem na abertura entre o rotor e o estator. No caso de quebra através do orifício, foi mostrado que a ruptura das gotículas ocorre somente a jusante da restrição, após percorrida certa distancia a partir da borda do orifício. Nesse comprimento de quebra, o gradiente radial de velocidade axial no escoamento é suficientemente grande para superar as tensões resistivas (exercidas pelas gotículas) e produzir a ruptura da gota. Esses resultados estão em concordância com as observações previas feitas por Galinat et al. (2005) para o caso de quebra de gota através de uma placa de orificio. No entanto, a partir das observações feitas neste trabalho, foi possível concluir que o comprimento do orifício não influencia os mecanismos de quebra. Também, a visualização permitiu analisar a influencia relativa da tensão interfacial e da viscosidade da fase dispersa para os dois casos considerados. Dados experimentais do tamanho de gota máximo estável foram obtidos para o caso de quebra de gota de emulsões de óleo em água diluídas nos dois casos estudados. A análise dos dados revelou que os tamanhos de gota 
máximos estáveis encontravam-se dentro da sub-faixa inercial, caracterizada exclusivamente pela taxa de dissipação de energia por unidade de massa, $\varepsilon$. Um modelo mecanístico linear para a sub-faixa inercial, baseado na teoria de turbulência isotrópica de Kolmogorov, foi desenvolvido para ajudar na interpretação dos dados e suprir uma base para correlação. O modelo foi ajustado aos dados experimentais utilizando uma ferramenta de otimização não linear baseada no código GRG2 (Generalized Reduced Gradient), e sua precisão calculada a partir da raiz quadrada media das diferenças entre os dados experimentais e os previstos. Boas previsões foram obtidas para o rompimento no misturador, no entanto, este não foi o caso da quebra através do orifício. A baixa precisão relativa do modelo utilizado para correlacionar a quebra através do orifício reside na falta de consideração da escala de tempo requerida para a ruptura. Além disso, uma regressão linear baseada em um modelo "Power Law" mostrou que os efeitos interfaciais dominam o processo de quebra de gota na restrição.

\section{Palavras-chave}

Quebra de gota; emulsões; visualização; escoamento turbulento. 


\section{Table of Contents}

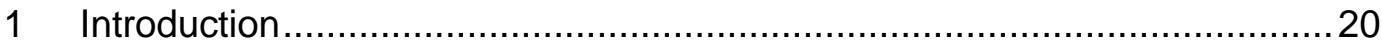

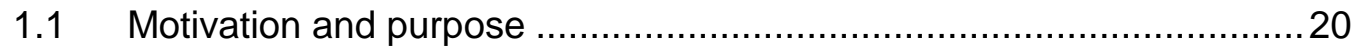

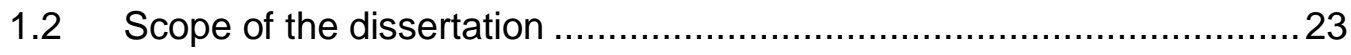

2 Turbulent drop breakup in the flow of diluted O/W emulsions.....................25

$2.1 \quad$ Basic principles of emulsions ....................................................... 25

2.1.1 Fundamentals ................................................................ 25

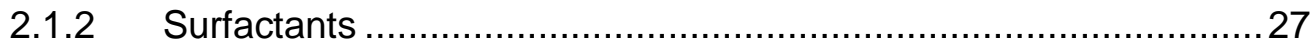

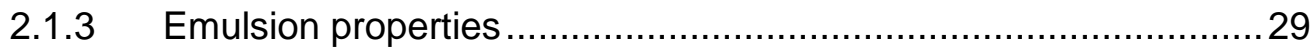

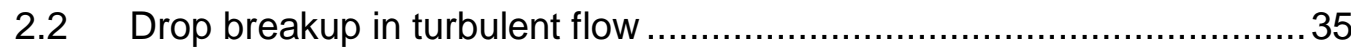

2.2.1 Introduction to turbulent flow .................................................. 36

2.2.2 Mechanistic model for drop breakup in turbulent flow ..................42

2.2.3 Hydrodynamics of drop breakup in turbulent flow ........................48

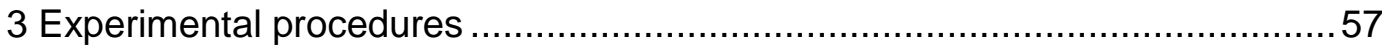

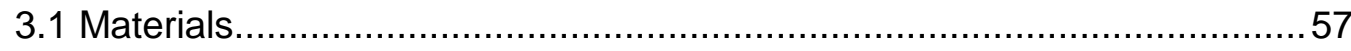

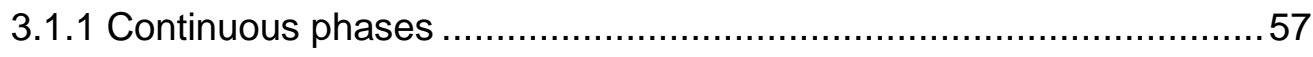

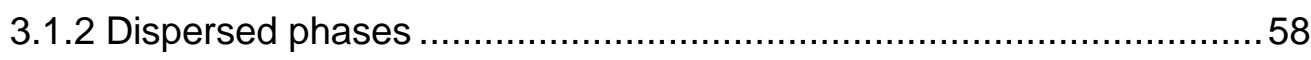

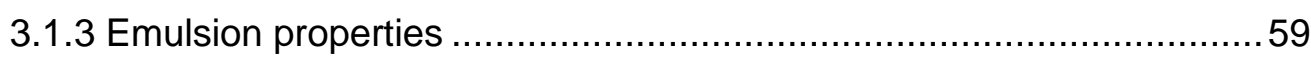

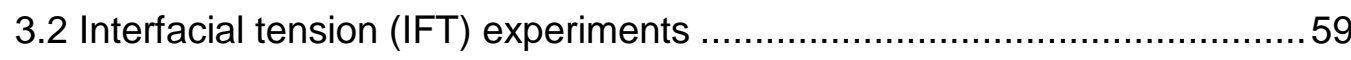

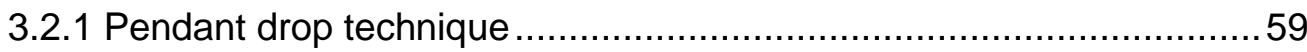

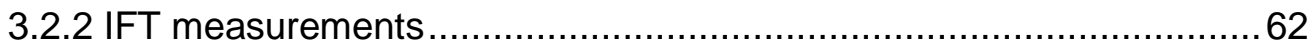

3.3 Experiments for visualization of drop breakup in turbulent flow................ 64

3.3.1 Visualization of drop breakup in a RSM ........................................65

3.3.2 Visualization of drop breakup through an orifice...............................68

3.4 Maximum Stable Drop Diameter (MSDD) experiments........................... 71

3.4.1 Measurement of Drop Size Distribution (DSD) ................................71

3.4.2 MSDD experiments for drop breakup in a rotor - stator mixer ............74

3.4.3 MSDD experiments for drop breakup through an orifice.................... 74

4 Results and discussion ............................................................... 77

4.1 Visualization of drop breakup in turbulent flow ................................. 77

4.1.1 Drop breakup mechanisms in a rotor - stator mixer ....................77

4.1.2 Drop breakup mechanisms through an orifice ............................84 
4.2 Maximum stable drop diameter correlations .....................................90

4.2.1 MSDD in the rotor - stator mixer.......................................... 91

4.2.2 MSDD in the flow through an orifice........................................95

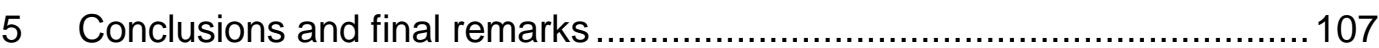

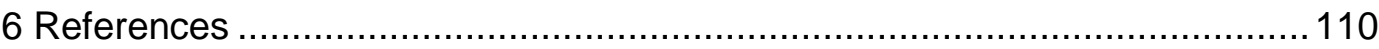




\section{Table of Figures}

Figure 1. 1 Diagram of a typical oil production system.

20

Figure 2. 1 Conventional representation of a generic surfactant molecule. (Copyright 2012. University of Waikato. All rights reserved. www.sciencelearn.gov.nz).

Figure 2. 2 Behavior of surfactants in a liquid-liquid system, a) concentration below the $\mathrm{CMC}$; b) concentration above the $\mathrm{CMC}$; $c$ ) curve equilibrium interfacial tension vs. logarithm of concentration for a typical surfactant. 29

Figure 2. 3 Common morphologies of emulsions. 30

Figure 2. 4 Inversion process for oil-water dispersion flow. (Adapted from Arirachakaran et al., 1989)

Figure 2. 5 Typical DSD in emulsions. 33

Figure 2. 6 Graphical definition of $d_{10}, d_{50}$ and $d_{90}$ in a DSD. 34

Figure 2. 7 Destabilizing mechanisms in emulsions. 35

Figure 2. 8 Decomposition of the instantaneous velocity component $U$ into a mean component $(\bar{U})$ and a fluctuating component $(u)$. 38

Figure 2. 9 Schematic representation of the energy spectrum of a turbulent flow.

Figure 2. 10 IKA T25 Basic RSM. 49

Figure 2. 11 a) Colloid mill. b) toothed device 49

Figure 2. 12 Axial discharge RSM Greerco XLR homomixer. 50

Figure 2. 13 Radial discharge RSM Silverson L4RT. 50

Figure 2. 14 Stator geometries considered in the Utomo, Baker and Pacek (2009) work. (a) disintegrating head, (b) slotted head, and (c) squared hole head. (Taken from Utomo, Baker and Pacek, 2009). 
Figure 2. 15 Flow patterns (radial and tangential velocities) of the jets emerging from different stators: (a) disintegrating head, (b) slotted head and (c) squared hole head. (Taken from Utomo, Baker and Pacek, 2009).

Figure 2. 16 Sketch of streamlines and pressure profile for flow through a circular orifice in a pipe. (Adapted from van der Zande et al., 1999).

Figure 3. 1 (a) Coordinates system for the pendant drop geometry. (b) Drop measurements needed to calculate shape factor $S$

Figure 3. 2 TRACKER (TECLIS) pendant drop tensiometer. 62

Figure 3. 3 Dynamic interfacial tension for dispersed phases in tap water as continuous phase. $\mathrm{T}=25^{\circ} \mathrm{C}$

Figure 3. 4 Dynamic interfacial tension for dispersed phases in surfactant based continuous phase. $\mathrm{T}=25^{\circ} \mathrm{C}$.

Figure 3. 5 (a) View of the IKA ULTRA TURRAX® T25 Basic mixer, (b) close up of the dispersing element, (c) view from beneath the dispersing element.

Figure 3. 6 Standard configuration for study the drop breakup process in a rotor - stator mixer.

Figure 3. 7 Experimental set-up for the visualization of breakup mechanisms in a RSM. Single droplet case.

Figure 3. 8 Schematic diagram of experimental set-up for visualization of the breakup of a single oil droplet through an orifice.

Figure 3. 9 Design of transparent device for visualization of turbulent drop breakup through an orifice.

Figure 3. 10 Experimental set-up for the visualization of breakup mechanisms in the flow through an orifice. Single droplet case.

Figure 3. 11 Laser diffraction technique to determine DSD. Taken from http://particle.dk/methods-analytical-laboratory/particle-size-by-laserdiffraction/laser-diffraction-theory/.... 72

Figure 3. 12 Malvern Mastersizer 2000 particle analyzer and Malvern Hydro 2000MU dispersing unit.

Figure 3. 13 Measurement cell of the Malvern Mastersizer 2000. 
Figure 3. 14 Schematic diagram of experimental set-up for determination of MSDD for drop breakup of diluted O/W emulsions through an orifice.

Figure 4. 1 Vortex and jet breakup mechanism in rotor - stator mixer.

$\mu_{d}=0.0178$ Pa.s, $\sigma=17.65 \mathrm{mN} / \mathrm{m}, \mathrm{T}=25^{\circ} \mathrm{C}$

Figure 4. 2 Mechanical breakup mechanism in the rotor - stator mixer.

$\mu_{d}=0.0178$ Pa.s, $\sigma=17.65 \mathrm{mN} / \mathrm{m}, \mathrm{T}=25^{\circ} \mathrm{C}$.

Figure 4. 3 Standard flow pattern in the high speed mixer. 80

Figure 4. 4 Breakup of a single droplet in a rotor - stator Mixer. High interfacial tension case. $\mu_{d}=0.192$ Pa.s, $\sigma=24.51 \mathrm{mN} / \mathrm{m}, T=25^{\circ} \mathrm{C}$

Figure 4. 5 Breakup of a single droplet in a rotor - stator mixer. Low interfacial tension case. $\mu_{d}=0.192$ Pa.s, $\sigma=1.79 \mathrm{mN} / \mathrm{m}, \mathrm{T}=25^{\circ} \mathrm{C}$.

Figure 4. 6 Breakup of a single droplet in a rotor - stator mixer. Low

dispersed phase viscosity case. $\mu_{d}=0.0178$ Pa.s, $\sigma=1.97 \mathrm{mN} / \mathrm{m}, \mathrm{T}=25^{\circ} \mathrm{C} . .82$

Figure 4. 7. Effect of dispersed phase viscosity on the drop size distribution of $\mathrm{O} / \mathrm{W}$ emulsions. $\varphi=0.05, \sigma \sim 1.9 \mathrm{mN} / \mathrm{m}$, Mixing Time $=2 \mathrm{~min}$, $\operatorname{Re}=27000, \varepsilon=46000 \mathrm{~W} / \mathrm{Kg}$.

Figure 4. 8 Effect of dispersed phase viscosity on the drop size distribution of $\mathrm{O} / \mathrm{W}$ emulsions. $\varphi=0.05, \sigma \sim 1.9 \mathrm{mN} / \mathrm{m}$, Mixing Time $=2 \mathrm{~min}$,

$\operatorname{Re}=50000, \varepsilon=290000 \mathrm{~W} / \mathrm{Kg}$.

Figure 4. 9 General scheme for turbulent drop breakup through an orifice.

$\mu_{d}=0.192$ Pa.s, $\sigma=24.51 \mathrm{mN} / \mathrm{m}, \beta=0.22$, Orifice Length $=5 \mathrm{~mm}$,

$\mathrm{T}=25^{\circ} \mathrm{C}$

Figure 4. 10 General scheme for turbulent drop breakup through an orifice.

$\mu_{d}=0.0178$ Pa.s, $\sigma=17.65 \mathrm{mN} / \mathrm{m}, \beta=0.22$, Orifice Length $=5 \mathrm{~mm}$,

$\mathrm{T}=25^{\circ} \mathrm{C}$

Figure 4. 11 General scheme for turbulent drop breakup through an orifice.

$\mu_{d}=0.192$ Pa.s, $\sigma=24.51 \mathrm{mN} / \mathrm{m}, \beta=0.22$, Orifice Length $=2 \mathrm{~mm}$,

$\mathrm{T}=25^{\circ} \mathrm{C}$

Figure 4. 12 General scheme for turbulent drop breakup through an orifice.

$\mu_{d}=0.192$ Pa.s, $\sigma=24.51 \mathrm{mN} / \mathrm{m}, \beta=0.44$, Orifice Length $=5 \mathrm{~mm}$,

$\mathrm{T}=25^{\circ} \mathrm{C}$

Figure 4. 13 Sequence of turbulent drop breakup downstream of an orifice.

$\mu_{d}=0.192$ Pa.s, $\sigma=24.51 \mathrm{mN} / \mathrm{m}, \beta=0.22$, Orifice Length $=5 \mathrm{~mm}$,

$\mathrm{T}=25 \stackrel{\circ}{\circ} \mathrm{C}$ 
Figure 4. 14 Droplet breakup and initial fragmentation in a high interfacial tension system (14 ms after the initial breakup). $\mu_{d}=0.0178$ Pa.s, $\sigma=17.65$ $\mathrm{mN} / \mathrm{m}, \beta=0.22$, Orifice Length $=5 \mathrm{~mm}, \mathrm{~T}=25^{\circ} \mathrm{C}$.

Figure 4. 15 Droplet breakup and initial fragmentation in a low interfacial tension system ( $6 \mathrm{~ms}$ after the initial breakup). $\mu_{\mathrm{d}}=0.0178 \mathrm{~Pa} . \mathrm{s}, \sigma=1.97$ $\mathrm{mN} / \mathrm{m}, \beta=0.22$, Orifice Length $=5 \mathrm{~mm}, \mathrm{~T}=25^{\circ} \mathrm{C}$.

Figure 4. 16 Evolution of the maximum drop size with the mixing time for different mixing speeds in the rotor - stator mixer. $\mu_{d}=0.192$ Pa.s, $\mathrm{T}=25^{\circ} \mathrm{C}$.

Figure 4. 17 Maximum stable drop diameter $\left(\mathrm{d}_{90}\right)$ and Kolmogorov's length micro scale for different values of energy dissipation rate per unit mass. Turbulent drop breakup of a $5 \% \mathrm{O} / \mathrm{W}$ emulsion in a rotor - stator mixer. $\sigma=1.79-1.97 \mathrm{mN} / \mathrm{m}, \mathrm{T}=25^{\circ} \mathrm{C}$

Figure 4. 18 Sauter mean stable drop size $\left(d_{32}\right)$ and Kolmogorov's length micro scale for different values of energy dissipation rate per unit mass. Turbulent drop breakup of a $5 \% \mathrm{O} / \mathrm{W}$ emulsion in a rotor - stator mixer. $\sigma=1.79-1.97 \mathrm{mN} / \mathrm{m}, \mathrm{T}=25^{\circ} \mathrm{C}$

Figure 4. 19 Linear and non-linear curve fittings to MSDD data for turbulent drop breakup of a $5 \% \mathrm{O} / \mathrm{W}$ emulsion in a rotor - stator mixer. $\mu_{d}=0.192$ Pa.s, $\sigma=1.79 \mathrm{mN} / \mathrm{m}, \mathrm{T}=25^{\circ} \mathrm{C}$

Figure 4. 20 Linear and non-linear curve fittings to MSDD data for turbulent drop breakup of a $5 \% \mathrm{O} / \mathrm{W}$ emulsion in a rotor - stator mixer. $\mu_{\mathrm{d}}=0.0178$ Pa.s, $\sigma=1.97 \mathrm{mN} / \mathrm{m}, \mathrm{T}=25^{\circ} \mathrm{C}$.

Figure 4. 21 Visual Estimation of Dissipation Length. $\mu_{d}=0.192$ Pa.s, $\sigma=$ $1.79 \mathrm{mN} / \mathrm{m}, \beta=0.22$, Orifice Length $=5 \mathrm{~mm}, \mathrm{~T}=25^{\circ} \mathrm{C}$

Figure 4. 22 Typical dimensions of the transparent device used for estimation of dissipation length.

Figure 4. 23 The length of dissipation zone versus $\beta$, the ratio between the orifice diameter and the pipe diameter. The dissipation length has been scaled with the pipe diameter. Adapted from van der Zande, 2000.

Figure 4. 24 Determination of MSDD for turbulent breakup through an orifice. Flow case 1. $\varepsilon=3.29 * 10^{4} \mathrm{~W} / \mathrm{Kg}$. 100

Figure 4. 25 Determination of MSDD for turbulent breakup through an orifice. Flow case 2. $\varepsilon=7.94 * 10^{4} \mathrm{~W} / \mathrm{Kg}$. 
Figure 4. 26 Determination of MSDD for turbulent breakup through an orifice. Flow case $3 . \varepsilon=15.11^{*} 10^{4} \mathrm{~W} / \mathrm{Kg}$.

Figure 4. 27 Determination of MSDD for turbulent breakup through an orifice. Flow case $4 . \varepsilon=25.23^{*} 10^{4} \mathrm{~W} / \mathrm{Kg}$. 101

Figure 4. 28 Maximum stable drop diameter and Kolmogorov's length micro scale for different values of energy dissipation rate per unit mass. Turbulent drop breakup of a $5 \% \mathrm{O} / \mathrm{W}$ emulsion through an orifice. $\sigma=1.79-1.97$ $\mathrm{mN} / \mathrm{m}, \beta=0.22$, Orifice Length $=5 \mathrm{~mm}, \mathrm{~T}=25^{\circ} \mathrm{C}$.

Figure 4. 29 Maximum stable Sauter mean diameter and Kolmogorov's length micro scale for different values of energy dissipation rate per unit mass. Turbulent drop Breakup of a $5 \% \mathrm{O} / \mathrm{W}$ emulsion through an orifice. $\sigma=$ $1.79-1.97 \mathrm{mN} / \mathrm{m}, \beta=0.22$, Orifice Length $=5 \mathrm{~mm}, \mathrm{~T}=25^{\circ} \mathrm{C}$ 103

Figure 4. 30 Linear and non-linear curve fittings to MSDD data for turbulent drop Breakup of a $5 \% \mathrm{O} / \mathrm{W}$ emulsion through an orifice. $\mu_{\mathrm{d}}=0.192 \mathrm{~Pa} . \mathrm{s}$, $\sigma=1.79 \mathrm{mN} / \mathrm{m}, \beta=0.22$, Orifice Length $=5 \mathrm{~mm}, \mathrm{~T}=25^{\circ} \mathrm{C}$.

Figure 4. 31 Linear and non-linear curve fittings to MSDD data for turbulent drop breakup of a $5 \% \mathrm{O} / \mathrm{W}$ emulsion through an orifice. $\mu_{\mathrm{d}}=0.0178 \mathrm{~Pa}$.s, $\sigma=1.97 \mathrm{mN} / \mathrm{m}, \beta=0.22$, Orifice Length $=5 \mathrm{~mm}, \mathrm{~T}=25^{\circ} \mathrm{C}$. 


\section{Table of Tables}

Table 2. 1 Mean drop sizes used to characterize emulsions. .33

Table 3. 1 STEOL CS-330 properties. $\mathrm{T}=25^{\circ} \mathrm{C}$.

Source:http://www.stepan.com/pdfs/Bulletins/STEOLCS330.pdf 58

Table 3. 2 Physicochemical properties of continuous phases. $\mathrm{T}=25^{\circ} \mathrm{C} \ldots \ldots \ldots . . . .58$

Table 3. 3 Physicochemical properties of dispersed phases. $\mathrm{T}=25^{\circ} \mathrm{C} \ldots \ldots \ldots . . . .59$

Table 3. 4. Equilibrium interfacial tension for oil-water systems. $\mathrm{T}=25^{\circ} \mathrm{C}$........64

Table 3. 5 Technical data for IKA ULTRA TURRAX® T25 Basic mixer. ..............66

Table 3. 6 Technical data for S25N - 18G - ST dispersing element. .................66

Table 4. 1 Experimental data obtained in MSDD determination for turbulent drop breakup in a rotor - stator mixer.

Table 4. 2 Calculated dissipation length from visualization experiments and from numerical simulations by van der Zande, 2000.

Table 4. 3 Experimental data obtained in MSDD determination for turbulent drop breakup through an orifice.

Table 4. 4 Comparison of Parameters obtained for the Linear Mechanistic Model. 


\section{Nomenclature}

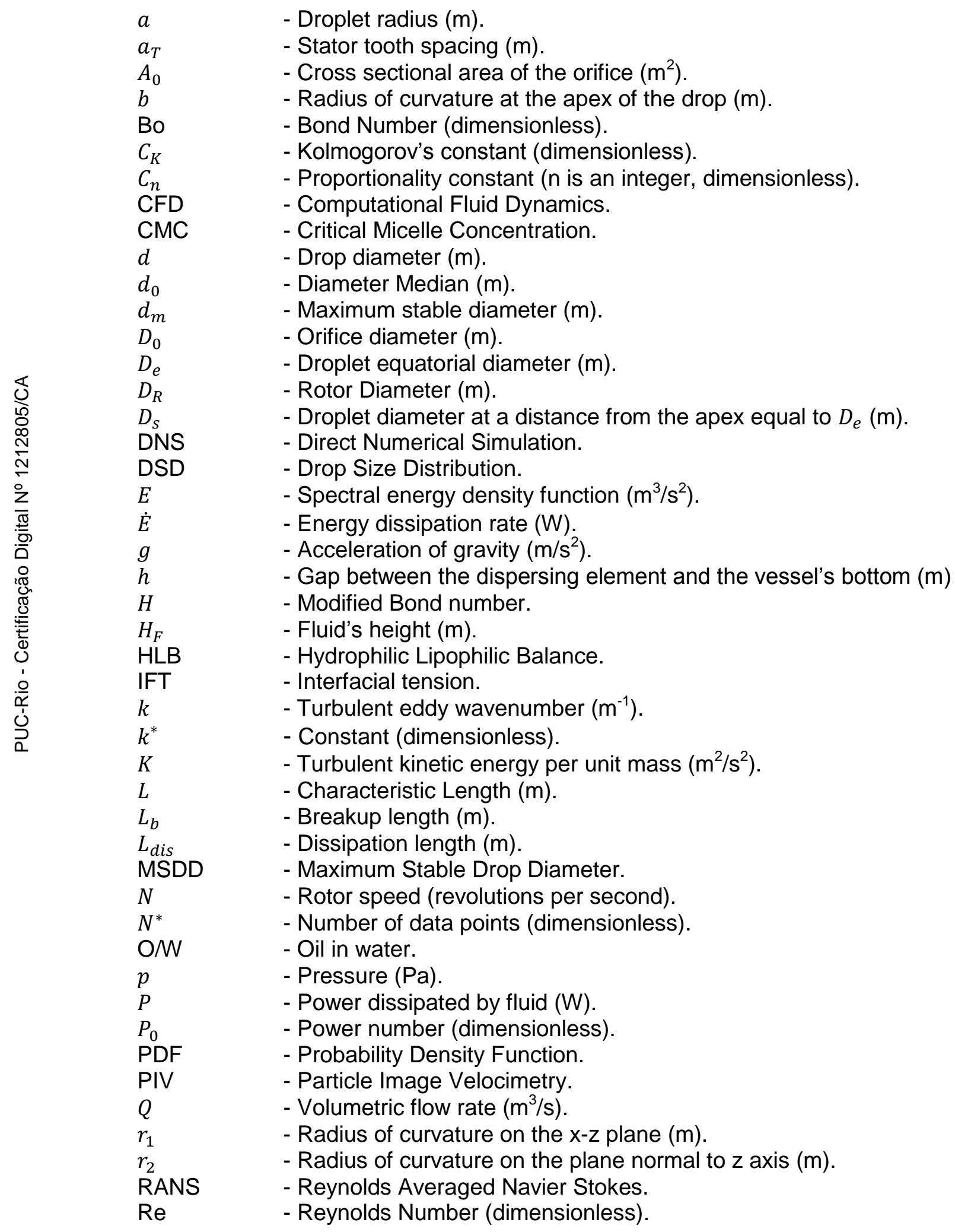




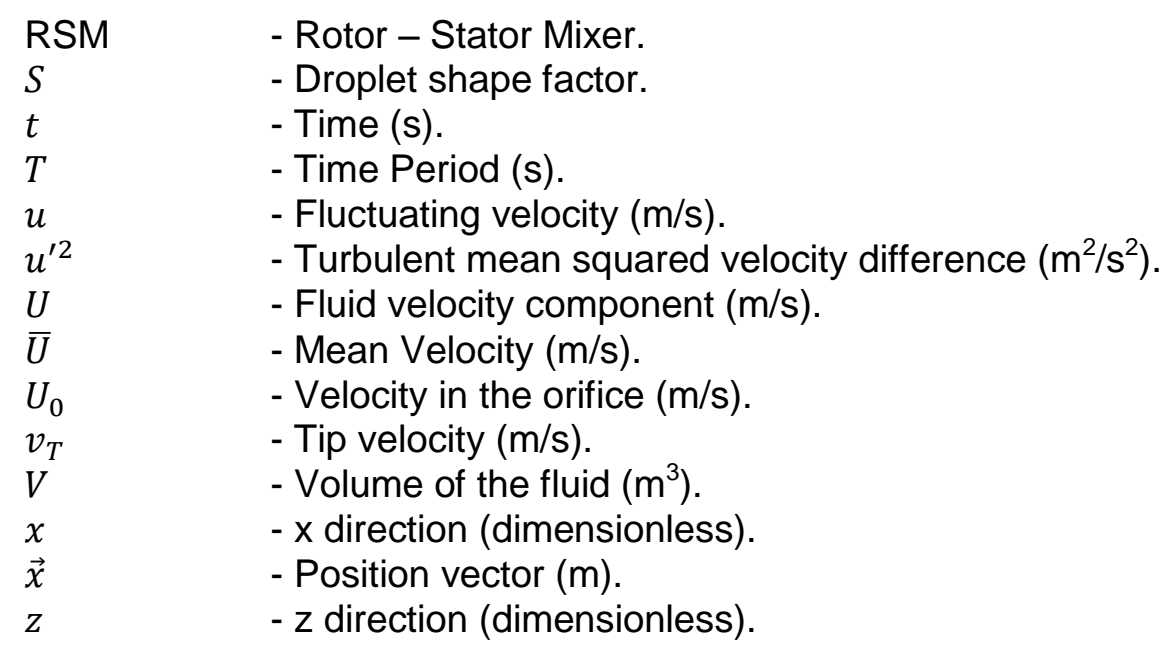

Greek Symbols.

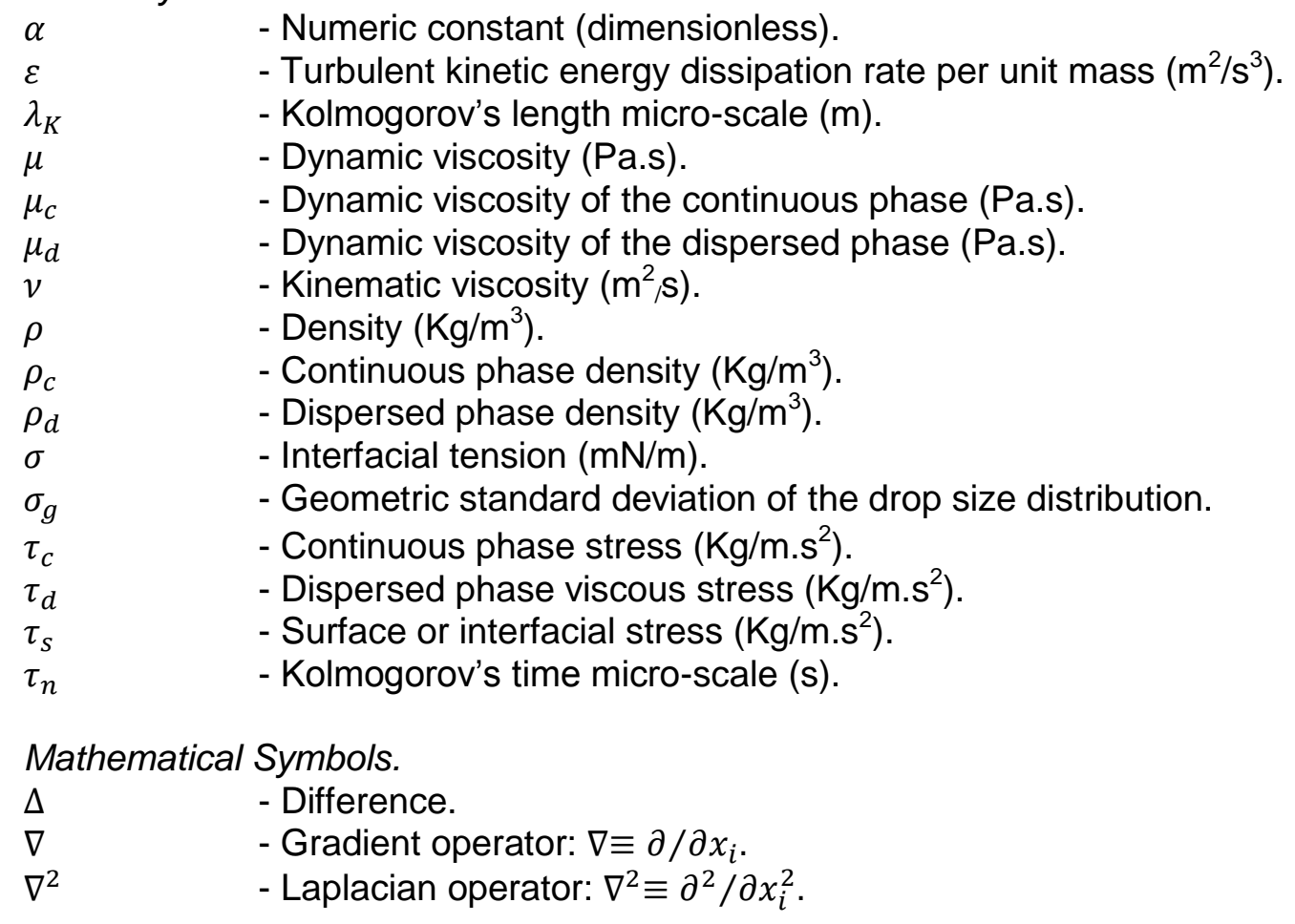

